\title{
Mini-Review \\ Modernity and the regulation of bodies: Elias meets Foucault
}

\author{
Carlos José Martins ${ }^{1}$ (D) Jorge Andrés Jiménez Muñoz ${ }^{1}$ (i) \\ ${ }^{1}$ Universidade Estadual Paulista, UNESP, Posgraduation Program in Human Develop- \\ ment and Technologies. Institute of Biosciences of Rio Claro, Rio Claro, SP, Brazil
}

\begin{abstract}
Aims: This article seeks to reflect on the possibility of a meeting ground where Michel Foucault and Norbert Elias' thought comes together around the issue of the regulation of drives and bodily practices within modernity. Such drives - among which we highlight the use of force and violence, as well as the acceptable regulation of their release and applications - have been the object of particular procedures within the modern era, whether seen in relation to individuals or from to the social body.
\end{abstract}

Keywords: the regulation of bodies, biopolitics, modern sport, civilizing process.

\section{Introduction}

Several chapters in the history of the body in modernity may be considered emblematic and relevant to the search for satisfactory and socially acceptable compromises to the problem of the governing and self control of the different drives, forces and conflicts originating in the bodies of individuals constituted through social practices. These drives - among which we could give particularly salience to the use of force and violence, as well as to the acceptable regulation of the way the latter are released and applied - have been the object of particular procedures in the modern era, whether seen from the perspective of individuals or approached from the angle of the social body. Approaches that are particularly worthy of merit may be found in the Michel Foucault's history of the emergence of disciplinary and bio-political practices and Norbert Elias' work on the socio-genesis of modern sport, both exemplary as distinctive theoretical contributions. The processes these thinkers describe and identify are, in origin, development and ramifications, phenomena that can be periodized in terms of the "long duration".

In this article, we intend to look at possible points of convergence in the contributions that these two authors make to our thought on the regulation of bodily practices and impulses within modernity. For such purposes, we will construct an overview of problems of the political management of bodies and populations within modernity, from the perspective of the "civilizing process".

The history of bodies can be approached from different perspectives. Bodies may be studied within the field of demography or from the point of view of historic pathologies. They may be seen as the site of needs and appetites, of physiological processes and metabolism, as the target of viral or microbian onslaught demonstrating to what extent historical processes were implicated in what could otherwise be considered the purely biological basis of existence. We could also look at the place that has been given within the history of societies to biological events such as the circulation of bacillus or efforts to prolong life itself.
On the other hand, we could put together a history of the ways in which bodily functions have been managed. For these purposes, we would assume a perspective in which supposedly natural functions reveal themselves as molded by their historical, political and social context.This was the case of the research carried out by the German Jewish sociologist Norbert Elias, through his theory of the civilizing process. At the helm of his theory, for the purposes that interest us here, are the parallels that he establishes between the different processes of internal pacification of individuals who have been constituted in society, the parliamentarization of conflicts over power, and the construction of the major institutions of the modern State and their correlated monopoly over the legitimate use of violence. Furthermore, such processes have been accompanied by the need to find socially acceptable forms for the search for excitement. In this regard, we can take the sociogenesis of sport as the emblematic example of his argument.

In this vein, the book which Elias published together with Eric Dunning, in 1986, The Quest for Excitement, is particularly noteworthy. Taking sport as symptom and instrument of civilization and civilizing processes, Elias and Dunning describe a scenario in which the phenomenon of modern sport takes on a previously unimaginable importance in history of the field of sociology. In other words, they argue that an understanding of sport is fundamental to the understanding of modern society.

\section{Disciplining bodies: Foucault's Contribution.}

In accordance with French philosopher Michel Foucault, bodies are directly situated within a political field. Power relations maintain a direct hold on bodies: they are invested in them, mark them, place demands on them, subject them to labor, thrust them into ceremonial rites, require their response. This political investment in bodies is linked, through complex, reciprocal relations, to the new demands of modern urban life and its economic deployment. As a productive force, bodies are invested with relations of power and domination. In 
compensation, their constitution as a productive force is only possible insofar as they are prisoners of a system of subjection, where need is also a political instrument, carefully organized, calculated and put to use. Bodies only become a useful force insofar as they become, at the same time, productive and docile. This subjection is not exclusively obtained through the use of instruments of violence and ideology. It may also be very direct, physical, involving force against force, acting over material elements without, nonetheless, really enacting violence. It can be calculated, organized, technically thought-out; it can be subtle, not employing the use of arms nor of terror, and yet continue to be a physical force. This means that there may be a "knowledge" of bodies that is not quite the science of their functioning; control over their forces is more than the ability to overpower them ${ }^{1}$. This knowledge and this control constitute what Foucault has referred to as the political technology of bodies. It is a diffuse technology, rarely formulated in continuous and systematic discourses; rather, discourse is often made of pieces and fragments, putting together material and processes that are not directly related. These technologies are disseminated throughout society, producing their effects by way of a wide variety of social practices, whether those of leisure, medicine, politics, etc.

Michel Foucault's original theoretical perspective identifies knowledge and political technologies that act upon bodies that are implicated both as individuals and members of a population. Within it, the disciplining of bodies and the regulation of populations are seen as the great analytical counterpoint of the widely-disseminated modern formal and juridical freedoms. Placed under the lens of the archeology and genealogy of techniques of government, bio-medical knowledge and medicine reveal their bio-political role in the constitution of our modern heritage.

In his The Birth of the Clinic Foucault ${ }^{2}$ demonstrated how medicine, over the course of a century, became a "national endeavor", decisively radicalized during the French Revolution and Empire. According to him, it was from this time that medicine became inseparable from State functions. This was how a new space came together, one in which the very epistemological and political structure of medicine underwent progressive modification. Furthermore, this would not occur only as a set of therapeutic techniques and knowledges, but also as a form of knowledge moving from the definition of a "not ill person" to that of a "model person". This meant a technology that aimed at regulating the physical and moral relationships sustained by individuals and by society, in which organic, balanced health, vigorous yet not based on passions, was connected to the national order, strong armies, the fertility of its people as well as their patient and ongoing labor, all linked in such a way as to fix the normative codes for the management of people's lives ${ }^{3}$.

In Chapter II, intitled "A political consciousness", Foucault reveals how in the years that came before and after the French Revolution, two major myths emerged: on the one hand, the myth of a national medical profession, structured similarly to that of the clergy and invested, at the level of health and bodies, with powers that were similar to those that were exercised over souls. On the other hand, the myth of the absolute disappearance of illness was propagated, in which passions and disturbances would vanish from society and an original, idyllic state of health obtained.

Thus, according to Foucault, from this historical moment on, the primary mission of the doctor would be political: the struggle against health problems would inaugurate a struggle against bad government and only free men would be truly "cured". In other words, insofar as politically efficient, medicine could then be dispensed with from a medical point of view. "And in a finally free society in which inequalities are pacified and harmony reigns, the doctor will have only a transitory role to play (p. 37-38)" 4 .

\section{Disciplinary power/ Political and anatomic.}

The studies that Foucault devotes to bio-medical knowledge and its correlate procedures are situated within the context of an "analytics of power relations". During the first part of the 1970s, Foucault defined and circumscribed what he referred to as "disciplinary power": power that is applied to individual bodies, through surveillance techniques, normalizing sanctions and a panoptical organization of institutional spaces.

The historical moment of the disciplines is the moment in which an art of the human body is born. It seeks not only to increase bodily abilities, nor deepen subjection, but fundamentally to form a new relationship within which the same mechanism makes the body more obedient as it becomes more useful, and vice versa. This breeds a politics of coercion that works on the body, a calculated manipulation of its elements, its gestures and its behaviors. The human body becomes part of a machinery of power that ransacks it, disarticulates it and re-composes it. A "political anatomy" that is also a "mechanics of power" is born; it defines how one may rule the bodies of others, not only to obtain compliance, but also so that they operate as one wants, with techniques, according to the speed and efficiency that has been determined. Discipline fabricates, in this way, submissive and exercised bodies, 'docile bodies'. Discipline increases bodies' strength (in economic terms of usefulness) and decreases these very strengths (in political terms of obedience). In one word: it disassociates bodily power, turning it on the one hand into an 'aptitude', an ability that it seeks to augment, and on the other, inverting the energy and power that could emerge from this and turns them into subjection in the strict sense. If economic exploitation separates strength from the product of labor, we could say that disciplinary coercion establishes in the body a coercive link between increased ability and accentuated domination [our translation from the Portuguese language version $]$ ( p. 127) $)^{5}$.

In "Discipline and Punish" ( "Surveiller et Punir" (1975)), Foucault embarked on major historical inquiry into the expansion of power's investment in bodies:

During the classical epoch, the body was discovered as object and target of power... a body that is manipulated and molded, trained, one the obeys and responds, becoming skilled, or whose strengths are multiplied. The grand book of the man-machine was written simultaneously in two registers: one, anatomo-metaphysical, whose first pages were written by Descartes and then taken up by doctors and philosophers; the other, technical and political, made up of a set of military, school and hospital regulations and by empirical, reflective processes to control or correct the body's 
operations. (...) The famous automats, in this regard, were not only one way to illustrate the organism; they were also political marionettes [our translation] (p.126-127) ${ }^{6}$.

\section{Bio-politics.}

Biopolitics consists in the management of a new problem: population growth in western Europe beginning in the 18th century. According to Foucault, bio-politics may be caracterized as a way of rationalizing the problems that governmental practice faces regarding issues pertaining to the management of the set of living beings that become a population.

The term "biopolitics" appears for the first time in 1974, in a conference on the birth of social medicine which Foucault gave at the State University of Rio de Janeiro (Universidade Estadual do Rio de Janeiro $)^{7}$. Foucault examined the rise of State medicine in Germany over the course of the 18th century, the emergence of urban medicine in France and efforts to medicalize the poor and the working classes in England.

Examining a literature made up of 18 th century police treatises, abundant yet long-neglected material, Foucault brings to light the strategic function of government forms in the history of the West. If, Foucault argues ${ }^{89}$, the development of governance - the set of means used to guide men, to direct and organize their behavior, to organize and orient their actions and reactions- becomes a particular landmark in the history of European society, we can then understand why such activities gave birth to a moment of reflection, to the means for conceptualizing their practices and implementation. In other words, there is a permanent rationalization that engenders objects, fields and methods for obtaining knowledge.

It is policing which, within the scenario of the new arts of governing, comes to the forefront as one of the fundamental techniques of the new order. It is what makes knowledge on the State, and knowledge of the dominions and goals that require State intervention possible, through knowledge of its strength and of all that may work to augment it.

Disciplinary power operates within two poles, that is, on the one hand, the individual and on the other, his/her position within the masses, in other words, as a member of the multitude. Disciplinary power turns those it seeks to control into a social body, but only after individually defining each of its members, through surveillance, correction and punishment. Thus, it is in placing individual bodies within a global mass affected by a series of processes that are a part of life, processes such as "birth, death, production, illness, that something such as bio-power could become constituted and incorporate the disciplinary apparatus"'(p. 23) ${ }^{10}$.

In spite of the fact that population issues had already been of concern for some time, it is only in the $18^{\text {th }}$ century that they became generalized. Given the considerable demographic growth that took place in Western Europe during that century, the need to coordinate and integrate it within the apparatus of production and the urgency to control it through more adequate and rigorous mechanisms of power came together to actually constitute something that could be thought of as "population". New types of knowledge come to be applied to this problem: demographics and observation related to the control of epidemics, among others. Furthermore, the apparatuses of power that engage not only observation, but also direct intervention, are created. Thus, not only a theoretical problem but an object of surveillance, analysis, intervention and transformative operations comes to be. Foucault argues that, as of this moment, something which can be referred to as power over life emerges ${ }^{11}$.

\section{Formation of the Modern State}

The phenomenon of the emergence of a power over life is contemporaneous with and condition of the possibility for the formation of modern Nation States, which find themselves in need of knowledge of their territory in order to evaluate how its inhabitants are distributed. This brings about the need to examine problems such as population growth rates and migratory flux. Most importantly, death and fertility rates, as well as the presence of epidemic and endemic phenomenon must be discovered, as well as all that which converges to determine the life conditions of populations, so that the appropriate instruments for efficient management are supplied, thereby reinforcing State power. This historic inflection marks the entrance of life within the realm of politics. This is Foucault's birth of biopolitics: life and its mechanisms are brought within the domain of explicit calculations which turn power and knowledge into agents of the transformation of human life. And in this way, human beings as a species are now at stake as the political strategies of Western societies are played out ${ }^{12}$.

Biomedical knowledge, as well as institutions providing health services, are thus called upon to play a fundamental role. This involves the tasks of prescribing the instruments and techniques of good government, describing the State, its configurations, powers and resources; they are meant in essence to develop and reinforce the life of individuals, as a necessary condition the State's strength and vigor.

From here springs Foucault's thesis, which, contrary to what certain critics of contemporary medicine sustain, indicates that, "modern medicine is a social medicine that is grounded in a certain technology of the social body". According to Foucault, medicine is a social practice that only in one of its aspects can be considered individualistic, invested in the relationship between doctor and patient ${ }^{13}$.

For Michel Foucault, capitalism as it developed at the end of the 18th and beginning of the 19th centuries socialized a first object, the body, as a force of production, labor and reproduction. In his view, societal control over individuals does not operate simply through consciousness or ideology, but begins in the body and through the body. It was in the biological, the somatic and the corporeal that capitalist society made its greatest investments. The body thus became a bio-political reality; medicine, urbanism and demography are bio-political strategies ${ }^{[1]}{ }^{14}$.

According to Foucault, it became evident that nature could not, by itself, as "Politia Naturae", sustain the regulatory 
functions of the life order; rather, States would have to guarantee this through medical policing. From this moment on, medicine was increasingly considered a fundamental element in the apparatuses of State security that would take charge of problems concerning urban space, the mass of population considered as an urban phenomenon, the family as an intense cell of social life and, finally, the bodies of individuals.

\section{Pastoral power and governance of bodies.}

The inclusion of life itself within the mechanisms of power, the governing of species and individuals considered as live bodies, the task of assuming responsibility for health problems and for the tutelage and protection of the nation's biological life, come together to make up the set of processes that characterize the advent of biopolitics. The intelligibility of such processes implies the abandonment, or at least reformulation, of the political categories that form the basis from which the question of power was historically understood within Western political tradition. Foucault identifies the originary model of this type of power within the religious tradition established by Christianity in the 3rd and 4th century, at the time when "pastoral power" came to be.

What does the singularity of this power consist of? It is a power that aims to guide and direct people throughout life and in each and every one of its circumstances, a power that seeks to take charge of people's existence in every detail, in order to guide their behavior and provide their salvation ${ }^{15}$.

Thus, Foucault is able to sketch out how the procedures and mechanisms of individualization and constitution of collective identities already established through the Christian pastoral became a fundamental resource in the birth of modern forms of the State and industrial societies. The former, in fact, had already cleared the ground for the new forms of governance of behavior. It is thus within the scenario of the processes of secularization of the Modern State that, according to Foucault, the "implantation, dissemination and multiplication of pastoral techniques throughout the lay cadre of the State apparatus" (p. $550){ }^{16}$ occurred. He expressed this in very explicit reference to Max Weber:

We are aware of how many times the issue of the role that a
moral ascetics had in the early formation of capitalism has been
raised; yet what took place in the 18th century in certain Western
countries, linked to the development of capitalism, was in fact
something else, perhaps of greater breadth that that new moral
that seemed to disqualify the body: it was no less than the entrance
of life into history - that is, the entrance of phenomena that are
proper to life into the order of knowledge and power - the field
of political techniques (p. 133) [our translation] $]^{17}$.

Thus, in accordance with Foucault's thesis, we are dealing with less of a moral or ideological phenomenon and more of a material, corporeal and technological one. At the heart of these important transformations, medicine plays one of its major historical functions, that, as of the 18 th century, consisted in "taking the place of religion and turning sin into illness" (p. 381) ${ }^{18}$.

\section{Hygienics and Eugenics.}

The emergence of public hygiene over the course of the 19th century would, for Foucault, be exemplary. It would enable the progressive integration of medicine as a decisive instance of social control and would also allow for its conversion into a discursive space where the "scientific" premises of species governance would be elaborated.

The hygienist program, through the great campaigns it carried out over the 19th century, was to engage in a wide range of interventions and controls which would allow medicine to become a global technique destined to guarantee the overall health of populations through the reduction of major epidemics, decreased death rates, the prolongation of life expectancy, etc. Thanks to public hygiene, medicine was, according to Foucault, able to take its places among administrative institutions, constituting itself as "medical administrative" knowledge, becoming "social medicine" (p. 209) ${ }^{19}$.

Social medicine was primarily put into action within the urban environment; the latter was the milieu where risks regarding population were to be managed. The localization of different neighborhoods, their physical conditions, the flow and quality of city air, sewage system and treatment, position of cemeteries and slaughterhouses and population density were all factors that played a decisive role in the mortality and morbidity rates of inhabitants. The city, with its major spatial variables, appears as an object of medicalization ${ }^{20}$.

Let us look at the problem of the city, or more precisely, this spatial disposition as thought out, conceived - the model city, the artificial city, the city of utopian reality, not only how it was dreamed up but how it was effectively set up in the 19th century. The workers' city, as it came to be in the 19th century - we can clearly see how it was articulated in a certain perpendicular way, with disciplinary mechanisms of control over the body, over bodies, its reframing, its setting up, where families (one in each house) and individuals (one in each room) were located. To set up, make individuals visible, normalizing behavior, a sort of spontaneous policing that was to be exercised through the spatial disposition of the city (p. 299) [our translation ${ }^{21}$.

Consequently, according to Foucault, medicine takes on an increasingly important role within administrative structures and, as of the 18th century, does not cease to expand and assert itself through its own machinery of power. Doctors infiltrate many different niches within State power and bureaucracy. Administration serves as a source of support, and at times, point of departure for major medical inquiries into the health of populations. An administrative medical knowledge takes shape, serving as the originary nucleus of 19th century "social economy" and sociology 22 .

For over more than a century, hygienist medicine represented the epistemological bases from which different branches of an entire range of biomedical, human and social sciences were to take shape and proliferate, as well as a psychiatyry guided by the model of degeneration and the disciplines of anthropology, sociology and criminology. It supplied a model of scientificity and a regime of truth for the racist practices of Eugenics that would soon be applied within liberal democracies and later, through the Nuremberg laws ${ }^{23}$. 
Foucault draws our attention to the role that medicine played in these historic circumstances:

And you understand, then, how in these conditions, how and why a technical knowledge such as medicine, or better yet, the set made up by medicine and hygiene, come in the 19th century to constitute an element, perhaps not the most important, but whose importance will become considerable given the link that is established between scientific influences over biological and organic processes (that is, over population and bodies) and at the same time, to the extent that medicine is to become a political technique of intervention, with its own power effects. Medicine becomes a knowledge-power that acts at the same time over bodies and over the population, over the organism and over biological processes and that, for these reasons, will have disciplinary and regulating effects (p. 301-302) [our translation] ${ }^{24}$.

It is now time to take a look at how, within the work of the great sociologist Norbert Elias, in whose background medicine and philosophy were also important, bodily phenomena also take on a crucial importance. He portrays their salience for grasping modern societies and the civilizing processes from which they emerge. The genesis of sport serves as an emblematic example of our main concern here. In Elias'view, there are deep and telling reasons for the wide acceptance and reception of the sporting phenomena that gain increasing expression and spread throughout the world, becoming a form of globalized social practice. Furthermore, his argument seems to represent a significant counterpoint to growing, detailed and expansive processes of bodily regulation within modernity revealed by Foucault's research which we have described above.

\section{Sport and civilization: the control of violence.}

Sport, as we know it today, as well as the life style associated with it, has not always existed, although a certain notion that is in vogue amongst us would have it this way. According to such an argument, sport began in ancient Greece, faded during the Middle (or "Dark") Ages and was reborn in the $19^{\text {th }}$ century through the Baron de Coubertin's Olympic movement. However, the pre-modern practices that preceded modern sport were almost always linked to ritual, religious or martial spheres, and may also be distinguished by a level of tolerance of violence that would be completely unacceptable for our times. It is only with the emergence of the modern world, and as a constitutive founding part of its culture, that sport emerges as an autonomous lay sphere, and from this point on, increasingly specialized and ever more influential in our lives.

According to the sociologist Norbert Elias, the emergence of modern sport in England over the course of the 18th and 19th centuries and its increasing global expansion may be seen as one of the most emblematic aspects of that which he denominated The Civilizing Process. One of the major characteristics of the social transformation he describes is an increasing capacity to exercise mastery and self-control within practices and physical activities of confrontation, a process which involves bringing the degree of violence down to acceptable levels. Thus, excitation is kept at satisfactory levels and its duration is measured, precisely to guarantee its fulfillment and the pleasure it brings to fruition. For these reasons, modern man gives sport an outstanding role, alongside the regulated and pacified processes for resolving political conflict and confrontations such as the State's monopoly of violence and the parliamentarization of power disputes. These are contemporary processes. For Elias these significant elements of the civilizing process are inseparable. Both at the macro and micro levels, sports and other institutional apparatuses for regulating and controlling violence and the use of power work as supports for what he calls the civilizing process. Thus, the same habitus is simultaneously manifested and formated within these different fields of heterogeneous practices.

Elias also looks at these dynamics to establish the significant characteristics of modern sport:

... sport is the activity of an organized group, centered around the confrontation of at least two parties. It demands a certain specific type of physical effort. It is carried out according to known rules which regulate the authorized limits on the exercise of violence, including those that define the degree and mode of physical force that can be practiced. There are rules that determine the initial configuration of players and their patterns of dynamics, in accordance with the unfolding of each competition (p. 230) [our translation $]^{25}$.

This difficult regulatory balance between control / lack of control over the use of physical force, producing both acceptable and desirable levels of pleasurable somatic excitement, is, for Elias, the fundamental characteristic of modern sport. In turn, this makes sport one of the most successful of modern cultural practices for controlling the unstable dynamic reigning over investments in aggressive drives and their regulation through liminality. It serves as a mechanism that not only delimits that which is tolerable but also that which is pleasant and sustainable in social practice.

In this way, both at the individual and collective level, "a controlled release of emotions" is at the base of sport and leisure and the role they play in Western civilization: a role involving the generation of tension through leisure, permitting the release of affects, and above all, aggressive drives, in a context that contains violence through rules set within a demarcated time and space. Thus, sport appears as the site, par excellence, of civilizing efforts, turning external coercion seeking to hold violence back into self-control. Elias provides a noteworthy illustration of the gradual transformation of the "emotional economy" with regard to the pacification of the social world, dislocating the regulation of tensions and the censure of affects and aggressive drives from outside of to within the individual.

Yet as Freud has taught us ${ }^{26}$, every effort to repress or control that the civilizing process imposes, through the inhibition and disciplining of our somatic drives, has its price, producing the malaise that is expressed, for example, in the paradigmatic case of neurotic suffering. Thus, as the father of psychoanalysis shows us, we are constantly challenged by the need to search for compromises in order to release repressed tensions so that they do not turn against their subjects, in pathological manifestations that can be both individual and collective. For these purposes, we seek out the different mechanisms of sublimation 
and catharsis. Here, we can highlight a variety of known forms of artistic and aesthetic pleasures. For the case in point, bodily arts and practices such as those of sport and leisure may prove themselves a particularly advantageous form of both sublimation and catharis, maximizing both the release of accumulated tensions and the mimetic pleasure of their practice. Thus, we can understand why it was this means of stylization of the deployment of aggressive drives that was so meticulously diagnosed by Norbert Elias in his research on the social role of sport and leisure in modern life ${ }^{27}$.

Norbert Elias also made considerable effort in bringing the cultural phenomenon of sport closer to other fields of culture, art in particular. To these ends, he evoked none other than Aristotle, in his work intitled Poetics, where for the first time the Greek philosopher discusses two of his key concepts: mimesis and catharsis.

For Elias, the imaginary in which sport appears as a mode of combat is, therefore - and notwithstanding the differences between them - related to the real struggles and conflicts of daily life. Thus, sport can be seen as an imitation of real-life conflict. Consequently, he expects the issue of imitation in sport to be treated with the same seriousness with which it is dealt with in relation to art. It is in this sense that he evokes the passage in Aristotle's Poetics which broaches the issue of imitation in Greek tragedy. He highlights the Greek philosopher's statement that "Tragedy is an imitation not of human beings, but of action and life, happiness and misery". It is in this sense that Elias believes to have identified its significant convergence with the mimetic problem in sporting practice. Furthermore, it was precisely within Aristotle's studies of Athenian leisure that the latter created the concepts of mimesis and catharsis, which Elias considers the most fertile concepts to be applied to this field of research. In effect, sport is destined to activate, to stimulate emotions and tensions as a form of controlled and balanced excitement, without evoking the risks and disturbances that may often be related to real life risk situations. Thus, sport may be seen as mimetic excitement which can be enjoyed and engaged in, providing a cathartic and liberating effect, even if the emotional vibrance link to imaginary conflict holds, as it often does, elements of anxiety, fear or despair.

Furthermore, Elias observes that although sport shares this mimetic character with many other social practices, it reveals singularities and differences in relation to them, and in particular, with regard to the arts, keeping in mind the preponderant role that struggles between human beings, strictu sensu, maintain within it. In other words, in all forms of sport, human beings engage in some kind of direct or indirect struggle. Certain types of sport in which goals are broadly similar to those of real confrontation between rival groups have a more accentuated tendency to unleash emotions and breed excitement. Thus, they represent a particularly strong example of one of the major problems of many sports: how to reconcile, by means of sporting objectives, two contradictory functions - on the one hand, the pleasure of unleashing human sentiment, producing agreeable feelings, and on the other, the preservation of a series of apparatuses of surveillance to keep the pleasurable release of emotions under control.
The concept of catharsis raises analogous issues. Sporting conflicts enable those engaged in them to win over rivals through physical struggles that avoid causing actual physical harm. And frequently, the tension of confrontation and efforts to win result in purifying and euphoric feelings. Thus, the beneficial effects of these practices can be perceived both at individual and collective levels.

\section{Final Considerations.}

Emerging more or less at the same time, as two currents in the constitution of modernity, we see on the one hand, a series of bodily disciplines that are meant to tame bodies and place them usefully at the disposal of modern life. On the other hand, we have sport, an extremely succesful means for regulating and releasing somatic excitation and an institution which expands and gains expressiveness around the world. Both sets of practices have had a profound effect both on individual bodies and over the population as a whole. Considered together as techniques of governance and self-governance, these practices were historically structured in consonance with the constitution of the modern State and lay at the heart of practices for pacification and regulation of political disputes. Certain practices were thus named by Foucault, characterizing power relations within modernity as anatomo-politics and biopolitics. In turn, Norbert Elias saw the sociogenesis of modern sport as one of the most significant expressions of the phenomena he identified within his theory of the civilizing process. That is to say - borrowing an expression from Freud - sport revealed itself as an emblematic compromise in terms of its ability to regulate the unstable dynamic of investments in agressive drives and control through liminality, demarcating not only what was tolerable but also what could be pleasant and sustainable in social practice. In this way, both at the individual and collective level, it permitted "a controlled release of emotions" that is the basis of sport and leisure and the role they play in Western civilization

Both of these authors, each with the singularity of his own thought, made enormous contributions to the critical diagnosis of the role of different forms oa regulation and self-governance of the functions and practices of bodies within modernity. Our purpose here has been to establish the possible convergences between them, while attempting to articulate them within a broad and complex panorama of the issues at stake.

\section{Endnotes}

${ }^{[1]}$ We should emphasize that Foucault used the term "bio-politics" for the first time in Brazil, precisely in this conference, given at the Institute of Social Medicine in Rio de Janeiro (Instituto de Medicina Social, UERJ) in 1977.

\section{References}

1. Foucault M. Vigiar e Punir. Ed. Petrópolis, Vozes, 1987.

2. Foucault M. O nascimento da clínica. Ed. Rio de Janeiro, ForenseUniversitária, 1987. 
3. Foucault M. O nascimento da clínica. Ed. Rio de Janeiro, ForenseUniversitária, 1987.

4. Foucault M. O nascimento da clínica. Ed. Rio de Janeiro, ForenseUniversitária, 1987.

5. Foucault M. Vigiar e Punir. Ed. Petrópolis, Vozes, 1987.

6. Foucault M. Vigiar e Punir. Ed. Petrópolis, Vozes, 1987.

7. Foucault M. O Nascimento da Medicina Social. In: Machado, R, coord. Microfísica do Poder. 3a. ed. Rio de Janeiro, Graal; 1984. p. $79-98$

8. Foucault M. "Omnes et singulatim": vers une critique de la raison politique. In: Defert D, Ewald F, Org. Dits et Écrits. Vol IV. Paris, Galimard; 1994. p. 134-161.

9. Foucault M. La technologie politique des individus. In: Dits et Écrits, v. IV. Defert, D, Ewald, F, editors. Dits et Écrits. Vol IV. Paris, Galimard; 1994. p. 813-828

10. Bertani M. Sur la généalogie du bio-pouvoir. Ed. Paris, ENS Éditons, 2001

11. Foucault M. Sobre a história da sexualidade. In: Machado R, coord. Microfísica do Poder. 3a. ed. Rio de Janeiro, Graal; 1984. p. $137-162$

12. Bertani M. Sur la généalogie du bio-pouvoir. Ed. Paris, ENS Éditons, 2001

13. Foucault M. O Nascimento da Medicina Social. In: Machado, R, coord. Microfísica do Poder. 3a. ed. Rio de Janeiro, Graal; 1984. p. $79-98$

14. Michaud Y. Des modes de subjectivation aux techniques de soi: Foucault et les identités de notre temps. Cités, Philosophie, Politique, Histoire. 2000; (2): 11-39

15. Foucault M. Dits et Écrits, v. III. Defert D, Ewald F, editors. Ed. Paris, Galimard, 1994

16. Foucault M. Dits et Écrits, v. III. Defert D, Ewald F, editors. Ed. Paris, Galimard, 1994

17. Foucault M. História da Sexualidade I: A Vontade de Saber. Ed. Rio de Janeiro, Edições Graal, 1985

18. Foucault M. Dits et Écrits, v. II. Defert D, Ewald F, editors. Ed. Paris, Galimard, 1994

19. Foucault M. Dits et Écrits, v. III. Defert D, Ewald F, editors. Ed. Paris, Galimard, 1994
20. Foucault M. A Política da saúde no Século XVIII. In: Machado R, Coord. Microfísica do Poder. 3a. ed. Rio de Janeiro, Graal; 1984. p. 107-113.

21. Foucault M. Em defesa da sociedade. Ed. Martins Fontes, São Paulo, 1999

22. Foucault M. A Política da saúde no Século XVIII. In: Machado, R, coord. Microfísica do Poder. 3a. ed. Rio de Janeiro, Graal; 1984. p. 107-113

23. Bertani M. Sur la généalogie du bio-pouvoir. Ed. Paris, ENS Éditons, 2001

24. Foucault M. Em defesa da sociedade. Ed. Martins Fontes, São Paulo. 1999

25. Elias N. Dunning, E. A Busca da Excitação. Ed. Lisboa, Difel, 1992.

26. Freud Sigmund. O mal-estar na civilização. Ed. Rio de Janeiro, Imago, 1974

27. Elias N. Dunning, E. A Busca da Excitação. Ed. Lisboa, Difel, 1992.

\section{Corresponding author}

Prof. Dr. Carlos José Martins

Universidade Estadual Paulista, UNESP, Posgraduation Program in Human Development and Technologies.

Institute of Biosciences of Rio Claro, Rio Claro, SP, Brazil

Email: Carlosjmartins@hotmail.com

Manuscript received on November 2, 2018

Manuscript accepted on November 25, 2018

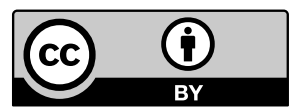

Motriz. The Journal of Physical Education. UNESP. Rio Claro, SP, Brazil - eISSN: 1980-6574 - under a license Creative Commons - Version 4.0 